\title{
Elevating Value Marketing Strategies in Singapore Airlines Driven by Macro and Micro Environment
}

\author{
Tian Qin ${ }^{1, *}$ \\ ${ }^{1}$ Coventry University of Singapore, Singapore 039594, Singapore \\ *Corresponding author. Email: cajwwwwer@126.com

\begin{abstract}
The present marketing plan is aimed at identifying the opportunities and strategic issues for Singapore Airlines. In this concern, the document presents a detailed analysis of the external environment including macro and micro environment that the company operates. The internal analysis of the company's marketing strategies and activities is presented to illustrate how effective operation of the company. As a result of these analyses, the report presents the issues and opportunities for the company that the company needs to consider to compete effectively in the airline industry. The ultimate purpose of the report is to propose strategies to deal with the identified issues and avail of the existing
\end{abstract} \\ opportunities.
}

Keywords: Singapore Airlines, marketing strategy, air industry, external market audit

\section{INTRODUCTION}

The present document intends to conduct an indepth analysis of the internal and external environment of the Singapore airlines. Singapore Airlines ("Fig. 1") is one of the leading international airline companies and a key player of in the Singapore airlines market with the support of state government. The company encompasses over 20 subsidiaries and has been catering to the international traveling market. Singapore airlines have a strong presence in the Asian market, particularly, in the southeast Asian market and are expanding in the American Market as well (Singapore
Airlines, 2019). The purpose of the analysis is to delineate how effectively the firm is operating in the current marketing environment. Moreover, the report aims to identify the strategic issues and opportunities that may culminate from the operational areas where the firm is lacking behind and the current market trends. Following this analysis, the reports set out strategic objectives for the resolution of the issues and plan strategies and tactics to achieve the desired objectives. A comprehensive plan of action is created for the implementation of the strategies and tactics and lastly, a brief control plan is presented.

\section{SIITGAPORE AIRLIIIES}

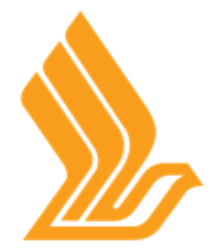

Fig. 1. The logo of Singapore Airlines.

\section{BUSINESS MISSION}

The business mission that drives the Singapore airlines towards its goals is to provide premium quality air traveling services to global travelers. The airlines' company also aims to act in the interests of its shareholders through the maximization of the
investment returns. 


\section{SitUATIONAL ANALYSIS OF SingAPORE AIRLINES}

The business mission of Singapore Airlines drives it towards its goals is to provide premium quality air traveling services to global travelers. The airlines' company also aims to act in the interests of its shareholders through the maximization of the investment returns.

\section{A. External market audit - macro analysis}

The airline industry pestle analysis is shown in "Table I".

\section{TABLE I. AIRLINE INDUSTRY PESTLE ANALYSIS}

\begin{tabular}{|c|c|c|}
\hline Factors & Description & Impact \\
\hline Political & $\begin{array}{l}\text { Singapore is a politically stable country posing no threat for businesses operating in the country. } \\
\text { Particularly for the airline sector, the government has been implementing expansion plans and } \\
\text { providing support (Kaur, 2018). } \\
\text { Also, Singapore Airlines is majorly owned by the state government with } 56 \text { percent voting rights. } \\
\text { Hence, the company receives enormous support from the government (Singapore Airline, 2014). }\end{array}$ & Favourable \\
\hline Economic & $\begin{array}{l}\text { Singapore is one of the wealthiest countries of south-east Asia. The economy heavily relies on trade } \\
\text { (BBC, 2018). } \\
\text { The country is characterized by a stable Gini coefficient due to the growing average household income } \\
\text { of the people (Statistics Singapore, 2018). } \\
\text { However, gasoline and fuel prices have significantly increased in the past year (Trading Economic, } \\
\text { 2020). This has caused profits of the airlines to plunge and the airlines are required to increase their } \\
\text { fares including the Singapore airlines to cope up with the rising fares (Straits Times, 2018). }\end{array}$ & Crucial \\
\hline Social & $\begin{array}{l}\text { Consumer preferences towards airlines are characterized by a diverse demand. Demand for the low-cost } \\
\text { carrier is rising, however, such demand is limited to the short-haul travels, the demand for long haul } \\
\text { travels is more characterized by premium preferences where customers demand full-services including } \\
\text { entertainment and food. This requires airline companies to create a diverse portfolio to meet customer } \\
\text { demands. Singapore Airlines is majorly a premium-class airline. However, to cater low-cost need it } \\
\text { offers low-cost long-haul carrier, Scoot while the full-service carriers, SilkAir are limited to the } \\
\text { regional travels. The long-haul full-service carrier of the company is declining (Ben, 2015). } \\
\text { As the customers are turning more price-sensitive, the rise of middle eastern airlines has taken } \\
\text { advantage by catering to the price-sensitive nature. This is a major threat for full-service carriers that } \\
\text { are solely targeting less price-sensitive business or upper class for the full-service carrier. These airline } \\
\text { companies have also gained popularity among Singaporean travelers (Martin Roll, 2019). } \\
\text { The demand for ultra-long-haul carriers is also increasing especially among the passengers traveling to } \\
\text { the North American region. Singapore airlines are at a geographic disadvantage to serve this region due } \\
\text { to high distance. This means that people, traveling from Singapore to North America have to opt for } \\
\text { connecting flights. Also, the demand for a premium economy product with full service is increasing } \\
\text { globally (CAPA, 2014). }\end{array}$ & Crucial \\
\hline Technological & $\begin{array}{l}\text { International companies, serving in Singapore, have been embracing technology for making long-haul } \\
\text { carrier service more comfortable and preferable for the passengers. Some airlines such as Thai airlines } \\
\text { and Emirates have offered efficient ultra-long-haul services to the customers to prevent the hassle of } \\
\text { connecting flights (Powley and Peggy, 2015). This requires Singapore airlines to focus on their long- } \\
\text { haul carrier service. }\end{array}$ & Crucial \\
\hline Legal & $\begin{array}{l}\text { The country has a strict legal and policy framework for the airlines. The airline company is abiding by } \\
\text { all the legal requirements from ensuing the aircraft health to taking measures for passengers' safety } \\
\text { (Singapore Airlines, 2017; Singapore Airliune, 2019). }\end{array}$ & Favorable \\
\hline Environmental & $\begin{array}{l}\text { In Singapore, people have become more environmentally conscious and have begun to prefer } \\
\text { businesses that have implemented eco-friendly standards in their business practices. This is evident by a } \\
\text { survey by WWF in which responses shows that two-thirds of the people support the ban on the } \\
\text { substance that is harmful to the environment (Hicks, 2019). With its CSR policies and measures to } \\
\text { reduce the carbon emission, the company is contributing its part in ensuring the sustainability of the } \\
\text { environment. This creates a positive image of the company in the mind of the consumers particularly } \\
\text { those that are conscious about environmental sustainability. }\end{array}$ & Favorable \\
\hline
\end{tabular}

\section{B. External market audit - micro analysis}

The airlines industry competitive analysis is shown in "Table II". 
TABLE II. AIRLINES INDUSTRY COMPETITIVE ANALYSIS

\begin{tabular}{|c|c|c|c|}
\hline Forces & Impact & Explanation & Key Factors \\
\hline Competitive rivalry & High & $\begin{array}{l}\text { The global airlines' industry is characterized by intense competition with several } \\
\text { competing firms based on the different service portfolio. Singapore faces fierce } \\
\text { competition from the middle eastern airlines that offer a diverse range of services } \\
\text { to the passenger form low-cost carriers to full-service carriers. Also, many North } \\
\text { Asian companies have started to give an intense competition in the ultra-long-haul } \\
\text { traveling to the North American region which is unserved by Singapore airlines. } \\
\text { Lastly, the middle eastern carrier has intensified the competition by targeting the } \\
\text { price-sensitive nature of the domestic as well as international travelers including } \\
\text { business travelers by providing full-service low-cost carriers. }\end{array}$ & $\begin{array}{l}\text { A large } \\
\text { number of } \\
\text { firms } \\
\text { Low } \\
\text { switching } \\
\text { cost }\end{array}$ \\
\hline $\begin{array}{l}\text { Threat of } \\
\text { New Entry }\end{array}$ & Low & $\begin{array}{l}\text { The airline industry is saturated by a large number of domestic and international } \\
\text { players. Some of the dominant names have achieved monopolistic advantage in } \\
\text { the market due to large product portfolios to cater to consumer demand. This } \\
\text { reduces the probability of new entrants in the market as it would need high capital } \\
\text { investment to establish a presence in such a market. }\end{array}$ & $\begin{array}{l}\text { High barriers } \\
\text { to entry } \\
\text { A large } \\
\text { number of } \\
\text { firms }\end{array}$ \\
\hline Supplier power & High & $\begin{array}{l}\text { The power of the suppliers is relatively high as there are few suppliers in the } \\
\text { aircraft industry. The market is dominated by Boeing and Airbus. Hence, this } \\
\text { duopoly increases the bargaining power of the suppliers. }\end{array}$ & $\begin{array}{l}\text { High } \\
\text { bargaining } \\
\text { power } \\
\text { Low } \\
\text { switching } \\
\text { cost }\end{array}$ \\
\hline Buyer Power & High & $\begin{array}{l}\text { The airline industry is characterized by the high bargaining power of the } \\
\text { customers as there are a large number of airline companies offering a wide variety } \\
\text { of services to the customers. }\end{array}$ & $\begin{array}{l}\text { High } \\
\text { bargaining } \\
\text { power } \\
\text { Low } \\
\text { switching } \\
\text { cost } \\
\end{array}$ \\
\hline Substitution threat & High & $\begin{array}{l}\text { With diverse service offers with various combinations of low cost, full service, } \\
\text { short-haul, long-haul and premium economy product, customers have a large } \\
\text { number of substitutes to choose form. }\end{array}$ & $\begin{array}{l}\text { The high } \\
\text { number of } \\
\text { alternatives } \\
\text { Low } \\
\text { switching } \\
\text { cost }\end{array}$ \\
\hline
\end{tabular}

Source: CAPA, 2014; IBIS World, 2019; Euromonitor International, 2019; Olieny and Carbaug, 2011; Martin Roll, 2019

\section{Internal market audit - marketing mix effectiveness}

The company has a diverse portfolio ("Fig. 2") with a variety of services at varying price points for international travelers. The airline company mainly focuses on the premium market for long haul full services; however, it has expanded its scope to add more service variety. SilkAir is a full-service short-haul carrier, Tigerair is a low-cost short-haul service and lastly, Scoot is a low-cost long-haul service (Singapore Airlines, 2019). With this wide portfolio, the company has added varying price points for the travelers. However, linking this to external analysis, it can be deduced that the company has no ultra-long-haul service. Also, Singapore Airlines' full-service carriers can be threatened by a middle eastern carrier with attractive price points. The company is present among Asian and American regions, but the geographic context does not encompass the North American market. In the context of promotional strategies, the company has integrated both traditional and digital media to target the customers (Singapore Airlines, 2019). 


\begin{tabular}{|c|c|c|c|}
\hline \multicolumn{2}{|c|}{ FULL SERVICE } & \multicolumn{2}{|c|}{ LOW COST } \\
\hline$\underbrace{\text { Singapore Airlines }}_{\substack{\text { SINGAPORE } \\
\text { AIRLInES }}}$ & SilkAir & $\begin{array}{l}\text { tigerair } \\
\text { Tigerair }\end{array}$ & Scoot \\
\hline $\begin{array}{c}\mathbf{1 8 , 9 9 0 , 1 6 6} \\
\text { passengers carried } \\
\text { in FY2016/17 }\end{array}$ & $\begin{array}{c}\mathbf{4 , 1 0 5 , 5 7 6} \\
\text { passengers carried } \\
\text { in FY2016/17 }\end{array}$ & $\begin{array}{c}5,145,835 \\
\text { passengers carried } \\
\text { in FY2016/17 }\end{array}$ & $\begin{array}{c}3,357,174 \\
\text { passengers carried } \\
\text { in FY2016/17 }\end{array}$ \\
\hline 106 & $\frac{30}{\text { aircraft in fleet }}$ & $\frac{23}{\text { aircraft in fleet }}$ & $\frac{12}{\text { aircraft in fleet }}$ \\
\hline 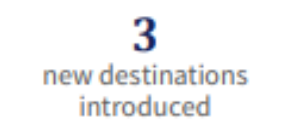 & 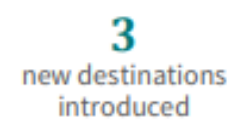 & $\begin{array}{c}12 \\
\text { cities served } \\
\text { in China }\end{array}$ & $\begin{array}{c}5 \\
\text { new destinations } \\
\text { introduced }\end{array}$ \\
\hline $\begin{array}{c}\mathbf{7 0} \\
\text { years of operation } \\
\text { in } 2017\end{array}$ & $\begin{array}{c}\mathbf{5 2} \\
\text { destinations in } \\
14 \text { countries }\end{array}$ & $\begin{array}{c}13 \\
\text { years of operation } \\
\text { in } 2017\end{array}$ & $\begin{array}{c}8 \\
\text { additional Dreamliners } \\
\text { on firm order }\end{array}$ \\
\hline
\end{tabular}

Fig. 2. Product portfolio.

\section{Internal market audit - STP effectiveness}

With such a wide portfolio, the company is targeting both upper- and middle-class groups. For fullservice carriers, the company has targeted solely the less price-sensitive business class community while low-cost carriers are characterized by a minimal amount of the services for the travelers. In this regard, the company has to face threats from the middle eastern airlines such as Qatar Airways and Emirate that is all set to cater the business travelers seeking full service and long-haul flights with attractive price points (Martin Roll, 2019). On the basis of the geographic context, the company targets certain regions of Asia and America encompassing 53 countries including New Zealand, Hongkong, Australia, Brazil, and India, etc. (Singapore Airlines, 2019). The company does not cater North American region due to high distance and lack of ultra-long-haul carrier service. In the context of psychographic segmentation, the company is targeted less price-sensitive quality-seeker upper class and business travelers and the price-sensitive travelers. This does not include business travelers that might be
Source: Singapore Airlines, 2017 enticed with attractive pricing offers. Lastly, on the basis of behavioural segmentation, the company has targeted only the international travelers of the country ("Fig. 3"). 


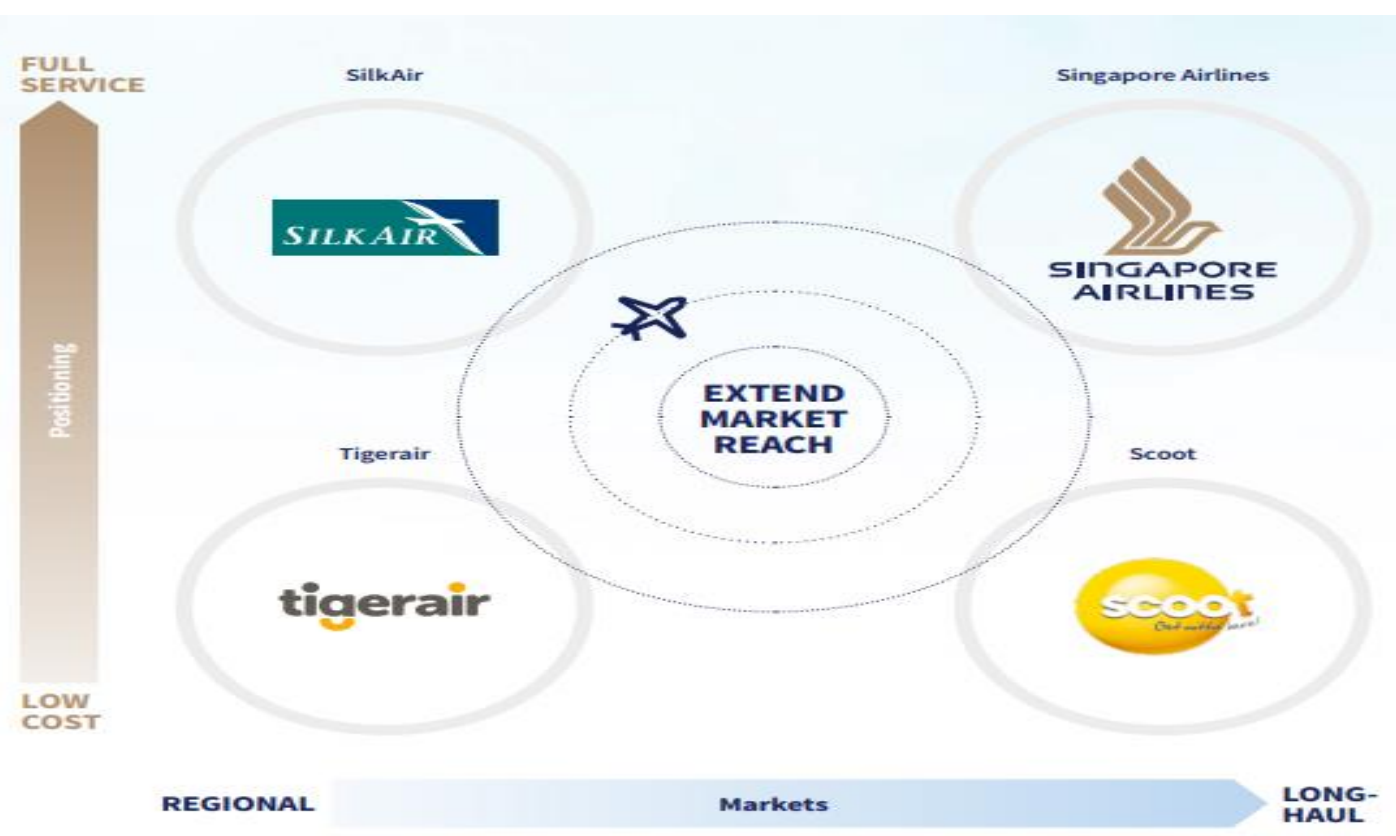

Fig. 3. Strategic development.

\section{STRATEgIC ISSUES OF SingaPORE \\ AIRLINES}

Establishing a link between the internal and external marketing audit, the author has been able to deduce the strategic issues and opportunities for Singapore Airlines:

- The company has no ultra-long-haul carrier service. Many global companies have introduced full service and comfortable ultra-long-haul routes. With Singapore Airlines, the Singaporean passengers that wish to travel to farther areas would have to opt for the connecting flights which are quite a hassle for business travelers.

- The company's full-service carriers are offered for the upper and upper-middle-class that is not sensitive to pricing. However, the middle eastern airlines serving in Singapore have begun to consider the price sensitivity of the business travelers and have started targeting them with the premium economy product.

- The company does not cater the travelers seeking to travel to the North American region, however, the demand for traveling to North America has been rising. This can be considered as the missed opportunity for Singapore Airlines.

- Lastly, the company does serve even a single route for catering domestic traveling within the country.

\section{SWOT ANALYSIS OF SINGAPORE AIRLINES}

From the above-conducted analysis of the internal and external environment, the report has extracted the following strengths and the weaknesses as well as the opportunities and threats that the company need to consider ("Table III"): 
TABLE III. SINGAPORE AIRLINES SWOT ANALYSIS

\begin{tabular}{|c|c|}
\hline $\begin{array}{ll}\text { Strengths } \\
\end{array}$ & Weaknesses \\
\hline $\begin{array}{l}\text { The company has a well-established brand name in the international } \\
\text { traveling market and is well known for premium quality services. } \\
\text { The company is characterized by strong government support. } \\
\text { Singapore Airlines has a wide portfolio with varying price points } \\
\text { catering long haul and short-haul international distances. } \\
\text { The company is targeting a diverse market on the basis of pricing. } \\
\text { The airlines' company has a large geographic network particularly in } \\
\text { Asia catering travelers that wish to travel outside the country }\end{array}$ & $\begin{array}{l}\text { Ticket prices are high especially for full-service carriers. } \\
\text { The airline company does not offer any ultra-long-haul services. } \\
\text { The lack of ultra-long-haul service has led to absence from the } \\
\text { North American market that is characterized by one of the highest } \\
\text { demanding traveling destinations. } \\
\text { The focus of the company is solely on the international market and } \\
\text { lack of presence in the domestic market. }\end{array}$ \\
\hline Opportunities & Threats \\
\hline $\begin{array}{l}\text { The company has the opportunity to expand its service portfolio to } \\
\text { new geographic regions. Moreover, it has been established that the } \\
\text { demand for traveling to North America is rising. The company can } \\
\text { include this market in its portfolio to increase its market share. } \\
\text { The company can also introduce carrier to facilitate the domestic } \\
\text { flights at premium pricing. } \\
\text { Singapore airlines have the opportunity to add ultra-long-haul routes } \\
\text { to tap on the business travelers that swish to avoid the bothersome } \\
\text { connecting flights. }\end{array}$ & $\begin{array}{l}\text { The rise of middle eastern companies has intensified the } \\
\text { competition. This is quite threatening to the company as these } \\
\text { companies have begun to cater to the price sensitivity of the } \\
\text { business travelers. } \\
\text { The North Asian companies serving in Singapore have also added to } \\
\text { the competition by offering ultra-long-haul carrier. With this, the } \\
\text { Singaporean travelers can travel to farther geographic regions } \\
\text { including the North American region. }\end{array}$ \\
\hline
\end{tabular}

\section{MARKETING OBJECTIVES}

On the basis of the internal and external marketing audit, the identified issues and the SWOT Analysis of Singapore Airlines, the report has developed the following marketing objectives for the company:

- To increase the revenue of the company by 10 percent over the period of next 1 year by adding the carrier service for catering the domestic flight within the country.

- To increase the market share of the company in the international market by adding more international destination while expanding in the new geographic locations such as North America.

- To cater to the price-sensitive nature of the business travellers of the country that might opt for some other airline due to high ticket pricing of the full-service carrier by Singapore Airlines.
In this regard, the company can categorize the full-service carriers into two catteries; premium product economy with a luxurious traveling experience and lower cost full-service carrier with mandatory business amenities such as video conferencing features etc.

- To cater to the needs of the international travelers that have to travel through longer distances by adding carrier service for ultralong-haul routes.

\section{CORE STRATEGY}

\section{A. Target market}

For the fulfilment of the aforementioned marketing objectives, the company is suggested to consider the following targets ("Table IV"):

TABLE IV. PROPOSED TARGET MARKET FOR NEW SERVICES

\begin{tabular}{|l|l|}
\hline \multicolumn{1}{|c|}{ Marketing Objective } & \multicolumn{1}{c|}{ Target Market } \\
\hline Domestic (In-country) flights & $\begin{array}{l}\text { Less price-sensitive in-country travelers that are willing to pay for air travel tickets for } \\
\text { domestic traveling. }\end{array}$ \\
\hline Lower cost full-service carrier & $\begin{array}{l}\text { Price sensitive business travelers that need amenities such as video conferencing, Wifi, } \\
\text { laptop, charging stations, screens etc. that cannot be found in the lower-cost long haul } \\
\text { carrier such as Scoot. }\end{array}$ \\
\hline Ultra-Long-haul carrier & Less price-sensitive people that are willing to pay more for avoiding connecting flights and \\
\hline
\end{tabular}




\section{B. Competitor targets}

With the suggested strategy, the company aims to give head-on competition to the middle eastern and North Asian airline companies that are disrupting the airline market, particularly in the Singaporean Airline market. With the category extension of the full-service long-haul carrier service, the company will be prepared to compete with the middle eastern airline. While, with the introduction of ultra-long-haul routes, the company will be able to compete with the North Asian airline companies.

\section{Competitive advantage}

Singapore Airlines already has a very diverse portfolio that covers varying pricing points. By expanding to add the suggested service offerings, the company will become a one-stop for all kinds of carriers achieving the cost leadership and premium quality service both.

\section{MARKETING MIX DECISIONS}

On the basis of the proposed marking objectives and the chosen target market, the following sets out the proposed marketing mix for the new services ("Table V"):

TABLE V. PROPOSED MARKETING IX FOR SINGAPORE AIRLINES

\begin{tabular}{|c|l|l|l|}
\hline Marketing mix factor & \multicolumn{1}{|c|}{ Domestic flights } & \multicolumn{1}{|c|}{ Lower cost full-service carrier } & \multicolumn{1}{c|}{ Ultra Long-haul carrier } \\
\hline Product & $\begin{array}{l}\text { Domestic carriers for traveling } \\
\text { within the country with premium } \\
\text { quality services }\end{array}$ & $\begin{array}{l}\text { Long-haul carrier with business } \\
\text { amenities but lesser luxurious than } \\
\text { premium long-haul service }\end{array}$ & $\begin{array}{l}\text { Ultra-long haul carriers for } \\
\text { American regions that are } \\
\text { farther. }\end{array}$ \\
\hline Price & $\begin{array}{l}\text { High pricing targeting upper and } \\
\text { business class that is willing to buy } \\
\text { domestic air tickets }\end{array}$ & $\begin{array}{l}\text { Lower price than the already exiting High pricing in return of } \\
\text { long-haul full-service carriers comfortable and seamless } \\
\text { targeting price-sensitive international } \\
\text { business travelers } \\
\text { thaveling experience for the } \\
\text { people that wish to avoid } \\
\text { connecting flights }\end{array}$ & \begin{tabular}{l} 
American regions \\
\hline Place
\end{tabular} \\
\hline Promotion & Singapore & Foreign locations & Digital and traditional media \\
\hline
\end{tabular}

\section{BUDGET}

For achieving the proposed marketing objectives, the company needs finance. In this regard, the report sets out the following budget forecast for the achievement of expansion strategies proposed to
Singapore Airlines. Since the proposed strategies are highly capital intensive and require massive finance, the following forecast only suggests the major share of major marketing activities in the recommended strategic initiatives and has been divided into four quarters for 1 year ("Table VI"):

TABLE VI. BUDGET FOR EXPANSION STRATEGIES

\begin{tabular}{|c|l|l|l|l|}
\hline Items & \multicolumn{1}{|c|}{$\begin{array}{c}\text { Cost/budget allocated for } \\
\text { 1st quarter }\end{array}$} & $\begin{array}{c}\text { Cost/budget allocated } \\
\text { for 2nd quarter }\end{array}$ & $\begin{array}{c}\text { Cost/budget allocated } \\
\text { for 3rd quarter }\end{array}$ & $\begin{array}{c}\text { Cost/budget allocated } \\
\text { for 4th quarter }\end{array}$ \\
\hline $\begin{array}{c}\text { Aircraft and capital } \\
\text { investment }\end{array}$ & 40 percent & & & \\
\hline $\begin{array}{c}\text { Marketing and } \\
\text { promotion Cost }\end{array}$ & 30 percent & 40 percent & 40 percent & 40 percent \\
\hline Maintenance & - & 20 percent & 20 percent & 20 percent \\
\hline Miscellaneous cost & 10 percent & 20 percent & 20 percent & 20 percent \\
\hline Human Resource & 20 percent & 20 percent & 20 percent & 20 percent \\
\hline
\end{tabular}

\section{ORGANIZATION AND IMPLEMENTATION}

The organization and implementation plan for the strategies are shown in "Table VII". 
TABLE VII. ORGANISATION AND IMPLEMENTATION PLAN FOR THE STRATEGIES

\begin{tabular}{|c|c|c|c|}
\hline Actions & Activities & Responsibility & Timeframe \\
\hline $\begin{array}{l}\text { Getting approval for } \\
\text { the planned strategic } \\
\text { initiatives }\end{array}$ & $\begin{array}{l}\text { The meeting will be conducted to present the company's } \\
\text { progress reports and market research to the directors, board and } \\
\text { the major stakeholders of the company. } \\
\text { The stakeholders will be informed about the need and } \\
\text { importance for the strategic initiatives and their feedback will be } \\
\text { taken. }\end{array}$ & Senior management & 1 month \\
\hline $\begin{array}{l}\text { Strategic planning for } \\
\text { expansion projects }\end{array}$ & $\begin{array}{l}\text { Project teams will be established to carry out the necessary } \\
\text { planning to implement the planned initiatives }\end{array}$ & $\begin{array}{l}\text { Board of directors } \\
\text { Senior management } \\
\text { Department heads }\end{array}$ & 1 month \\
\hline $\begin{array}{l}\text { Deciding the } \\
\text { requirements } \\
\text { associated with the } \\
\text { financial budget }\end{array}$ & $\begin{array}{l}\text { The budget will be formulated for the planned expansion } \\
\text { initiatives. }\end{array}$ & $\begin{array}{l}\text { Senior Management } \\
\text { Board of directors } \\
\text { Finance department }\end{array}$ & 1 months \\
\hline $\begin{array}{l}\text { Communicating the } \\
\text { plan to the employees }\end{array}$ & $\begin{array}{l}\text { A communication plan will be established to systematically } \\
\text { communicate the initiatives to all the organisation members } \\
\text { Meetings will be conducted to announce the strategic initiatives }\end{array}$ & $\begin{array}{l}\text { Senior Management } \\
\text { HR department } \\
\text { Department heads }\end{array}$ & 1 month \\
\hline $\begin{array}{l}\text { Acquisition of aircraft } \\
\text { and infrastructure } \\
\text { development }\end{array}$ & $\begin{array}{l}\text { Capital investment will be made to acquire equipment, aircraft } \\
\text { and amenities. }\end{array}$ & $\begin{array}{l}\text { Board Members } \\
\text { Senior management }\end{array}$ & 8 months \\
\hline
\end{tabular}

\section{CONTROL}

\section{A. Evaluation}

After the implementation of the planned initiatives, it would be of significant importance to evaluate the progress of the integrated strategic initiatives and their impact on the overall performance of the company. Hence, the last stage is to evaluate the results produced by the marketing plan. Quarterly performance review reports will be generated to keep track of the performance. Moreover, benchmarks will be created using industry reports and established marketing objectives. These will be compared to the performance reviews to analyse the effectiveness of the marketing plan. To analyse the customer preference for the Singapore airlines, feedback can also be taken from the customers that can be used to evaluate the experience of the passengers. By doing so, the management will not only be able to get insights about the audience experience but will also be able to identify areas that can be further improved.

\section{B. Reporting protocols for evaluation}

To evaluate the performance and keep the track of the performance, the project teams will be responsible for developing performance review reports including the details regarding the financial as well as the nonfinancial performance of the company. The performance review reports will be presented to the senior management and the board of directors. The recorded findings will be reviewed in the performance review meetings to analyse the performance established targets. Moreover, the recorded data will also enable the management top to analyse the gaps that may exist in the progress and if the planned initiatives are progressing in the right direction.

\section{CONCLUSION}

The report conducted an in-depth analysis of Singapore Airlines. In this regard, a thorough audit of the internal and external market activities has to be executed. As a result of this, the report was able to identify opportunities and issues for the company that can be considered to achieve market success. Conclusively, it was found that the company is solely focused on international travelers and has no carrier service for facilitating domestic flights. This can be treated as an opportunity for increasing revenues. Moreover, Singapore Airlines faces intense competition from the middle eastern airlines that are catering to the price-sensitive business travellers and threatening the full-service carrier offerings of the company. In this regard, the company can cope up with this intensified competition by adding a lower-cost full-service longhaul traveling option for business travelers.

Lastly, it was found that many companies particularly north Asian airline companies have developed their ultra-long-haul carrier service for travelers that wish to avoid the connecting flights. However, the company lacks ultra-long-haul service. This is the reason; the company is unable to cater to travelers traveling to the North American region. Hence, with the introduction of the ultra-long-haul carrier, the company will be able to increase its market share by expanding its services in the North American region. The report has also proposed an implementation 
plan and the plan for controlling and evaluating the progress of the marketing plan.

\section{References}

[1] BBC., 2018. Singapore country profile. BBC. Retrieved from https://www.bbc.com/news/world-asia-15961759

[2] Ben, L., 2015. What has been shaking up the airline industry. One Mile at a Time. Retrieved from https://onemileatatime.com/singapore-airlines-unprofitable/

[3] CAPA, 2014. Singapore Airlines SWOT: challenges continue as competition intensifies as shown by 1QFY2015 results. Informa Markets. Retrieved from https://centreforaviation.com/analysis/reports/singaporeairlines-swot-challenges-continue-as-competition-intensifies-asshown-by-1qfy2015-results-180289

[4] Euromonitor International, 2019. Airlines in Singapore. Euromonitor International. Retrieved from https://www.euromonitor.com/airlines-in-singapore/report

[5] Hicks, R, 2019. Is Singapore's green movement for real? EcoBusiness. https://www.eco-business.com/news/is-singaporesgreen-movement-for-real/

[6] IBIS World, 2019. Global Airlines Industry - Market Research Report. IBIS World. Retrieved from https://www.ibisworld.com/global/market-researchreports/global-airlines-industry/

[7] Kaur, K., 2018. Parliament: Changi Airport to put part of profits into government funds to support expansion, deal with crises. Singapore Press Holdings Ltd. Retrieved from https://www.straitstimes.com/politics/parliament-changi-airportto-put-part-of-profits-into-govt-funds-to-support-expansion-deal

[8] Olienyk, J. and Carbaugh, R.J., 2011. Boeing and Airbus: Duopoly in Jeopardy?. Global Economy Journal, 11(1), p.1850222.

[9] Powley, T., and Hollinger, P., 2015. A new era of 'ultra-longhaul' aviation. The Financial Times Ltd. Retrieved from https://www.ft.com/content/689a1618-814d-11e5-8095ed1a37d1e096

[10] Singapore Airlines., 2014. Financial Results for Year Ended 31 Mar 2014. Singapore Airlines. Retrieved from https://www.singaporeair.com/saar5/pdf/InvestorRelations/Annual-Report/annualreport1314.pdf

[11] Singapore Airlines, 2017. Annual Report. Singapore Airlines. Retrieved from https://www.singaporeair.com/saar5/pdf/InvestorRelations/Annual-Report/annualreport 1617.pdf

[12] Singapore Airlines, 2019. Annual Report. Singapore Airlines. Retrieved from https://www.singaporeair.com/saar5/pdf/InvestorRelations/Annual-Report/annualreport1819.pdf

[13] Statistics Singapore., 2018. Key Household Income Trends, 2018. Department of Statistics Singapore. Retrieved from https://www.singstat.gov.sg//media/files/publications/households/pp-s25.pdf

[14] Straits Times., 2018. Airfares set to rise as airlines grapple with higher fuel prices. Singapore Press Holdings Ltd. Retrieved from https://www.straitstimes.com/singapore/transport/air-faresset-to-rise-as-airlines-grapple-with-higher-fuel-prices

[15] Trading Economic., 2020. Singapore Gasoline Prices. Trading Economics. Retrieved https://tradingeconomics.com/singapore/gasoline-prices 